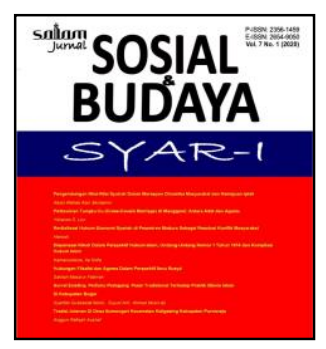

\title{
Metode Cina dalam Mengatasi Covid-19; Analisis dengan Menggunakan Teori The Law of non Transferability of Law*
}

\author{
Muhammad Asadurrohman ${ }^{1}$ Fakhruddin ${ }^{2}$ Noer Yasin ${ }^{3}$ \\ UIN Maulana Malik Ibrahim Malang \\ do \\ $10.15408 / \mathrm{sjsbs} . v 8 \mathrm{i} 4.21081$
}

\begin{abstract}
The ups and downs of COVID-19 were motivated by the neglect of the rule of law. China was the first country to be affected by COVID-19 as well as a country that managed to overcome it. This success is the result of the hard work of the Chinese government and its people. The theory initiated by Seidman emphasizes the existence of a good legal culture, but every rule of law that is successfully enforced in one place cannot necessarily be applied elsewhere. The purpose of this study was to find out the methods of preventing the spread of COVID-19 used by China and their relevance to other countries in the application of these methods. This is done by using Seidman's theory as an analytical knife. This research method is qualitative-normative literature-based. The results showed that China implemented a system of lockdown and Chinese Medicine (CM).
\end{abstract}

Keywords: Coping with COVID-19, legal culture, Seidman's theory.

\begin{abstract}
Abstrak
Pasang-surut COVID-19 dilatarbelakangi adanya pengabaian aturan hukum. Cina merupakan negara yang pertama kali terkena dampak COVID-19 sekaligus sebagai negara yang berhasil menanggulanginya. Keberhasilan tersebut merupakan hasil dari adanya kerja keras yang dilakukan oleh pemerintah Cina dan masyarakatnya. Teori yang digagas oleh Seidman menekankan adanya budaya hukum yang baik, namun setiap aturan hukum yang berhasil diberlakukan di suatu tempat tidak semerta-merta bisa terapkan oleh tempat lain. Tujuan penelitian ini adalah untuk mengetahui metode pencegahan penyebaran COVID-19 yang digunakan oleh Cina dan relevansinya dengan negara-negara lain dalam penerapan metode tersebut. Demikian dilakukan dengan menggunakan teori Seidman sebagai pisau analisis. Metode penelitian ini adalah kualitatif-normatif yang berbasis kepustakaan. Hasil penelitian menunjukkan bahwa Cina menerapkan sistem lockdown dan Chinese Medicine (CM).
\end{abstract}

Kata Kunci: Penanggulangan COVID-19, budaya hukum, teori Seidman.

* Received: May 03, 2021, Revision: May 25, 2021, Published: August 5, 2021.

1 Muhammad Asadurrohman merupakan Mahasiswa Program Studi Magister al-Ahwal alSyakhshiyyah Pascasarjana UIN Maulana Malik Ibrahim Malang. (Email: baadhlminkul@gmail.com)

2 Fakhruddin merupakan Dosen di Fakultas Syari'ah dan Pascasarjana UIN Maulana Malik Ibrahim Malang.

${ }^{3}$ Noer Yasin merupakan Dosen di Fakultas Syari'ah dan Pascasarjana UIN Maulana Malik Ibrahim Malang. 


\section{A. PENDAHULUAN}

Hukum secara sepintas dapat kita gambarkan sebagai suatu aturan yang mengikat bagi sekelompok manusia yang hidup dalam suatu golongan, atau merupakan suatu aturan yang mengatur tata tertib kehidupan diantara mereka. Membahas tema hukum dan sosiologi hukum tentu saja tidak bisa melepaskan siapa yang menghendaki diskusi ini dari pembahasan mengenai hukum dan efektivitasnya di dalam merealisasikan suatu hukum itu sendiri. Hal ini mengingat beberapa adagium masyhur dalam dikursus ilmu hukum, yakni "Ubi Societes ibi Ius" yang dapat diartikan sebagai hukum yang timbul berdasarkan keadaan sosial. Di mana keberadaan suatu objek hukum - (masyarakat) yang menuntut timbulnya suatu hukum itu sendiri." Atau suatu adagium yang menyatakan bahwa "Hukum untuk manusia bukan manusia untuk hukum". Adagium yang kedua tersebut dapat dipahami dari dua sudut pandang, sudut pandang yang pertama merupakan pengejawantahan dari apa yang dimaksud di dalam adagium yang pertama. Sedangkan sudut pandang yang kedua memberi pemahaman bahwa manusia dalam hal ini sangat bergantung dengan hukum. Kedua sudut pandang tersebut sejatinya sangat berkaitan erat dengan kedua adagium yang telah penulis sebutkan di atas. Pada intinya kehadiran suatu hukum adalah mutlak untuk menertibkan kehidupan manusia yang hidup di dalam suatu kelompok sosial. Pada adagium yang kedua dapat diuraikan bahwasanya dikatakan "hukum untuk manusia" mengindikasikan bahwa hukum diartikan sebagai suatu aturan yang timbul demi ketertiban dan kemaslahatan manusia itu sendiri. Sedangkan dikatakan "bukan manusia untuk hukum" karena memang peran penegak hukum disini diartikan sebagai pengelola suatu hukum yang telah ada di dalam suatu kelompok manusia. ${ }^{5}$

Dalam diskursus sosiologi hukum, jika suatu aturan hukum dirasa tidak memberi dampak positif, bahkan dirasa menjadi penghambat atas kemajuan dan kemaslahatan suatu anggota dalam kelompok manusia maka seharusnya pertimbangan terhadap efektivitas suatu hukum harus benar-benar diperhatikan. Bahkan perubahan suatu aturan hukum demi efektivitas yang dirasa lebih mendukung ketertiban masyarakat sangat memungkinkan untuk dilakukan. ${ }^{6}$ Betapa banyak para akademisi kontemporer yang sangat intens dalam hal memprioritaskan sosiologi hukum di dalam menegakkan suatu hukum. Diantaranya sebagaimana yang disampaikan oleh Munir Fuadi di dalam bukunya ${ }^{7}$ bahwa salah satu peran signifikan ilmu sosiologi hukum adalah untuk memecahkan berbagai persoalan hukum. Lebih jauh ia menyatakan bahwa:

Banyak persoalan hukum dewasa ini sudah tidak lagi memuaskan jika hanya diselesaikan oleh sektor hukum secara normatif saja, buktinya - keadilan semakin jauh

${ }^{4}$ Ahmad Tahali, "Hukum Adat di Nusantara Indonesia", Jurnal Syariah Hukum Islam, No. 2 (Oktober, 2018), hlm. 69.

${ }^{5}$ Ulfa Budiana dan Muhammad Djafar Saidi, "Efektivitas Penegakan Hukum Pajak Bagi Wajib Pajak Hotel, Al-Azhar Islamic Law Review, No. 1 (Januari, 2020), hlm, 59.

${ }^{6}$ Muhammad Yusuf, "Efektivitas Pelaksanaan Hukum Jinayat di Aceh", Samarah; Jurnal Hukum Keluarga dan Hukum Islam, No. 1 (Januari, 2019), hlm, 120.

${ }^{7}$ Munir Fuady, Teori-teori dalam Sosiologi Hukum, Cet. 1 (Jakarta: Kencana, 2011), hlm, 1. 
dari harapan. Karena itu diperlukan pendekatan yang lebih komprehensif, utamanya meminta bantuan ilmu sosiologi untuk memecahkan berbagai persoalan hukum yang dihadapi oleh masyarakat.

Tidak berbeda jauh dengan realitas hukum Islam kontemporer dewasa ini, diskursus kajian hukum benar-benar diposisikan sebagai suatu kajian yang mengatur tentang ketertiban dan penopang atas kebutuhan suatu kepastian hukum bagi suatu golongan masyarakat. Berbeda dengan konsep kajian hukum Islam klasik, di mana masyarakatlah yang diharuskan untuk mengikuti aturan-aturan yang telah dirumuskan, dalam hal ini fikih. ${ }^{8}$

Kisaran sejak awal tahun 2020 hingga dewasa ini seharusnya tidak ada lagi yang patut untuk mengabaikan eksistensi COVID melalui bukti riil atas merambaknya virus tersebut. Hal itu dapat dilihat secara bersama-sama melalui realitas yang terjadi hingga dewasa ini, di mana semua pihak merasa dibebani tanggung jawab dalam rangka pengentasan virus tersebut, jajaran pemerintah, ormas-ormas, dan setiap individu bangsa harus saling bergandengan tangan dan mendukung satu sama lainnya. Oleh karena itu asumsi awal mayoritas publik terhadap eksistensi COVID-19 yang hanya bersifat lokal, yakni tidak mungkin akan terjadi penularan besar-besaran yang menyebar ke seluruh penjuru negara harus dilenyapkan. Hal itu baru dirasakan dan disadari ketika data yang dipublikasikan oleh masing-masing negara menunjukkan peningkatan angka kematian akibat klaim COVID-19 terus mengalami peningkatan. Kejadian semacam itu sejatinya tidak boleh terjadi, karena upaya preventif merupakan cara terbaik daripada menunggu kemudharatan datang baru dilakukan penanganan.

Tercatat bahwa hingga bulan Mei 2020 beberapa negara seperti Prancis, Spanyol, Iran, Italia, dan Amerika Serikat yang notabene memiliki label sebagai negara maju berdasarkan penilaian publik mencatat korban yang terdampak mencapai ribuan orang, kemudian meningkat menjadi puluhan ribu, bahkan mencapai kisaran jutaan jiwa. ${ }^{9}$ Korban jiwa di Amerika Serikat justru - menempati peringkat pertama dalam hal banyaknya kasus COVID yang terjadi. Dengan meningkatnya dampak tersebut beberapa pihak kemudian mempertanyakan kemapanan Amerika sebagai negara maju. Mengingat telah merambaknya pandemi COVID-19 di lebih dari 200 negara di dunia, maka persoalan ini patut untuk dipandang sebagai permasalahan global, bukan masalah satu atau beberapa negara saja.

Kendati demikian Cina sebagai suatu negara kini dianggap sebagai salah satu negara yang berhasil melakukan pencegahan atas penyebaran Covid $-19 .{ }^{10}$ Dari sedikit

8 Soleh Hasan Wahid, “Dinamika Fatwa dari Klasik ke Kontemporer (Tinjauan Karakteristik Fatwa Ekonomi Syariah Dewan Syariah Nasional Indonesia, DSN-MUI), Yudisia; Jurnal Pemikiran Hukum dan Hukum Islam, No. 2 (Desember 2019), hlm, 193.

${ }^{9}$ Lihat Vina Fadhrotul Mukaromah, “China Tak Lagi Masuk Daftar, Ini 10 Negara dengan Kasus COVID-19 Terbanyak di Dunia", dalam https://www.google.com/amp.kompas.com/tren/read/2020/05/02/094100465/ , diakses pada tanggal 14 Juni 2021.

${ }^{10}$ Dalam salah satu surat kabar dikatakan bahwa Amerika justeru menganggap China lamban dalam penanganan terhadap COVID-19. Oleh karena itu Amerika bersama dengan Israel, dan beberapa 
latar belakang tersebut dan demi menopang kebutuhan akan efektivitas kajian sosiologi hukum, dalam tulisan ini penulis memaparkan beberapa sudut pandang Cina terhadap Pandemi Covid-19 dan metode yang digunakannya sehingga berhasil mengatasi penyebaran Covid-19. Dari paparan tersebut penulis melakukan suatu analisis dengan menggunakan teori yang digagas oleh Robert B. Seidman ${ }^{11}$ _untuk selanjutnya ditulis seidman_ The Law of non Transferability of Law.

\section{B. METODE PENELITIAN}

Dalam penelitian ini metode yang digunakan adalah kualitatif dengan menjadikan studi dokumenter (library reseach) sebagai alat pengumpulan data. Adapun metode analisis yang digunakan di dalam penelitian ini adalah menjadikan salah satu teori yang diusung oleh salah seorang tokoh hukum dan ilmu politik untuk menganalisis data primer dan mengkaitkannya dengan realitas penanganan COVID-19 yang diberlakukan di Indonesia.

Karena penelitian ini termasuk ke dalam jenis penelitian kepustakaan maka dalam hal teknik pengumpulan data yang penulis lakukan adalah dengan cara studi dokumenter, baik secara offline (perpustakaan) maupun secara online (seperti jurnal, websait, dan yang dianggap memiliki kelayakan untuk dirujuk dalam proses pengumpulan data). Setelah dilakukan pengumpulan data maka yang harus dilakukan adalah menganalisis data dan menarik kesimpulan terkait paparan data tersebut guna memberikan jawaban atas rumusan masalah yang telah diuraikan pada bagian pendahuluan tulisan ini.

\section{HASIL TEMUAN DAN PEMBAHASAN}

\section{Cina dan Perkembangan Covid-19}

Pada tanggal 11 Maret 2020, organisasi kesehatan dunia atau yang lebih dikenal dengan sebutan WHO (World Health Organization) menyatakan bahwa wabah penyakit akibat COVID-19 merupakan pandemi global. Status ini diakibatkan kasus positif di luar negara Cina yang terus mengalami peningkatan yang sangat drastis di sekitar 114 negara dengan total korban _pada saat itu_ mencapai 4,291 orang meninggal dunia yang diklaim terdampak COVID-19. WHO juga menyatakan bahwa selama ini belum pernah ditemukan pandemi yang dipicu oleh virus corona dan belum pernah ada pandemi yang dapat dikendalikan. Atas dasar itulah WHO

negara lain melakukan tuntutan ke Pengadilan Federal atas gugatan seputar sumber wabah tersebut. Lihat Rehia Sebayang, "Dituntut 90 Ribu T Gegara Corona, Ini Jawaban Cina ke AS", dalam https://www.cnbcindonesia.com/news/20200422083748-4-153543/, diakses pada tanggal 14 Juni 2021.

${ }^{11}$ Robert B. Seidman (24 Februari 1920 - 3 April 2014) merupakan intelektual hukum Amerika dan Profesor dalam bidang Hukum dan Ilmu Politik di Universitas Boston, Massachusetts, Amerika Serikat. Karya tulisnya kebanyakan dimuat dalam bentuk makalah-makalah penelitian dan beberapa tertuang dalam buku, diantaranya buku dengan judul The State, Law, and Devlopment, State and Law in the Devlopment Process: Problem-Solving and Institutional Change in the Third World. Lihat https://en.m.wikipedia.org/. 
berharap para petinggi negara-negara dunia untuk dapat mengambil tindakan mendesak dan agresif dalam rangka mencegah dan mengatasi penyebaran COVID19.12

Dalam perkembangannya, COVID-19 pertama kali menyerang kawasan Wuhan, Cina pada Desember 2019 lalu, hingga April 2020 telah menyebar hingga kurang lebih ke 210 negara dunia. Dengan karakterististik penyebarannya yang sangat cepat di antara manusia, ditambah lagi dengan mobilitas manusia yang sangat tinggi dan lintas batas negara menjadikan virus tersebut memiliki tingkat penyebaran yang lebih tinggi, sehingga sangat mudah menyebar. Berdasarkan data dari Worldometer hingga 23 April 2020, kasus positif akibat virus tersebut telah mencapai 2,7 juta jiwa di seluruh dunia di mana Amerika Serikat, Spanyol dan Italia menempati tiga peringkat teratas sebagai negara dengan kasus tertinggi di dunia, mengalahkan Cina. ${ }^{13}$

COVID-19 memunculkan problematika baru bagi negara-bangsa, khususnya mengenai bagaimana upaya suatu negara untuk mencegah dan menghentikan penyebaran virus tersebut agar tidak terus merambak. Vaksin sosial seperti kebijakan pemberlakuan social distancing dan lockdown pun dilakukan oleh beberapa negara sebagai salah satu respons atas situasi dan kondisi darurat semacam ini. Cina dalam hal ini menunjukkan respons yang serius terhadap eksistensi COVID-19. Realitas tersebut menunjukkan bahwa telah terjadi pergeseran kekuatan global dari Barat menuju ke Timur. ${ }^{14}$

\section{Metode yang digunakan Cina dalam Mencegah Penularan Covid-19}

Penyebaran Covid-19 yanng semakin erambak ke penjuru dunia mengakibatkan tidak sedikit orang yang menekan pemerintah dan aparat untuk menerapkan lockdown. Setidaknya sepertiga dari populasi dunia hidup di bawah kebijakan lockdown atau penutupan wilayah dan tak lagi bebas bepergian akibat Covid-19 yang semakin menyebar. memberlakukan lockdown di Kota Wuhan sejak 23 Januari. Penduduk di sana dilarang keluar kawasan tanpa izin. Beberapa negara pun mengikuti langkah Cina itu. Italia, India, Spanyol, dan Inggris merupakan beberapa negara yang menerapkan lockdown secara ketat berskala besar di seluruh negeri. Namun, masing-masing negara memiliki mekanisme berbeda dalam menerapkan aturan itu, dari menutup perbatasan wilayah hingga melarang warga keluar rumah.

Cina dianggap sukses melakukan pencegahan terhadap penyebaran Covid-19 dengan lockdown. Namun, ada pula negara yang justru menjadi rancu sejak lockdown berlangsung. Beberapa bulan lalu, Cina melaporkan hingga ribuan kematian akibat virus corona, termasuk para dokter dan perawat.

12 Lihat dalam https://www.who.int., diakses pada 20 Mei 2020.

${ }^{13}$ Lihat Nanih Machendrawaty, Yuliani, dkk., “Optimalisasi Fungsi Mesjid di Tengah Pandemic Covid 19 (Telaah Syar'i, Regulasi dan Aplikasi)", KTI UIN Sunan Gunung Djati Bandung, (2020), hlm, 5.

${ }^{14}$ Idil Syawfi, "Implikasi Pandemi Covid-19 Terhadap Hubungan Internasional: Menuju Dunia Paska-Liberal", Jurnal Ilmiah Hubungan Internasional, (2020), hlm, 25. 
Negara tersebut sempat tercatat sebagai negara dengan jumlah kasus dan kematian paling banyak di seluruh dunia. Pemerintah akhirnya memberlakukan lockdown. Sekitar dua bulan penduduk Cina, khususnya Wuhan, terjebak dalam rumah karena isolasi ketat yang diberlakukan pemerintah. Semua perusahaan tak strategis dan sekolah ditutup. Perkumpulan publik dibatasi, operasional transportasi publik dihentikan. Pemerintah hingga swasta rajin menyuplai kebutuhan pangan selama lockdown berlangsung. Namun, meski pasokan makanan sebagian besar warga terjamin, sejumlah penduduk mengaku mengalami kekurangan makanan. Beijing bahkan menggunakan teknologi pengawasan kuat, termasuk menerbangkan drone dilengkapi kamera termal untuk meningkatkan deteksi virus. Berkat lockdown dan sederet upaya lain oleh pemerintah Cina, jumlah infeksi baru virus corona di Wuhan menurun drastis. Rumah sakit darurat yang dibangun untuk menangani pasien corona telah ditutup. Dua pekan terakhir Cina beberapa kali melaporkan nihil kasus infeksi domestik harian. Provinsi Hubei kini dibuka kembali. Perkantoran dan pabrik mulai beroperasi, sekolah dibuka, dan penduduk kembali beraktivitas normal. Data Johns Hopkins University menunjukkan, hingga Selasa (31/3) pagi, sebanyak 76.192 orang dari 82.240 pasien positif Covid-19 di Cina dinyatakan sembuh. Sementara itu, jumlah korban meninggal 3.309 jiwa. ${ }^{15}$

Italia, Lonjakan kasus virus corona di Italia membuat pemerintah memberlakukan lockdown. ${ }^{16}$ Jumlah kematian corona paling banyak di dunia berasal dari Italia yakni 11.591 dari total 101.739 pasien terinfeksi virus. Sekitar 60 juta warga Italia juga tak lagi bebas bergerak karena pemerintah membatasi perjalanan, waktu luang, pekerjaan, hingga kegiatan keagamaan masyarakat termasuk termasuk upacara pemakaman. Pemerintah menutup - sekolah, museum, gedung olahraga, bar, restoran, dan pertokoan. Warga hanya bisa membeli bahan makanan di supermarket dengan maksimal waktu belanja 30 menit dan tak diizinkan berkumpul di tempatumum.

Namun, masih banyak warga yang menganggap remeh, sehingga virus menginfeksi lebih banyak orang. Rumah sakit di Italia bahkan mulai tak mampu menampung pasien, banyak yang akhirnya menjalani perawatan di rumah. Pemerintah Italia pun memberlakukan aturan lockdown ebih ketat. Mereka menaikkan denda bagi warga yang tak patuh hingga 400 sampai 3.000 euro (sekitar Rp7 juta sampai Rp52,6 juta). Menyusul lockdown diterapkan, pasien meninggal karena virus corona di Italia mulai menurun. Wakil Menteri Kesehatan Pierpaolo Sileri mengatakan data terbaru menunjukkan penurunan jumlah orang yang terinfeksi dalam sepekan terakhir. Namun, dilaporkan Sky News, Selasa (30/3), beberapa orang di Italia mulai putus asa. Mereka meminta bantuan pemerintah karena kehabisan uang dan makanan. Sejumlah orang

15 Lihat Nurul Khusnul Khoimah, "Lockdown COVID-19 ditinjau dari Teori Filsafat, Pancasila sebagai Filsafat dan Bentuk Negara Indonesia", Academia (2020), hlm, 3

16 Lihat, Luigi Bellomarini, Marco Benedetti, dkk., "COVID-19 and Company Knowladge Graphs: Assessing Golden Powers and Economic Impact of Selective Lockdown via AI Reasoning", Arxiv Preprint, (April, 2020), hlm, 4. 
bahkan rela keluar dan mencuri makanan untuk dikonsumsi. Laporan kasus harian masih mengalami kenaikan hingga delapan persen, setelah sebelumnya sempat melonjak hingga 50 persen di awal Maret. Pemerintah pun memperpanjang lockdown hingga pertengahan April.

India, Pemerintah India menyerukan lockdown selama 21 hari untuk menekan penyebaran virus corona. Seluruh perbatasan ditutup untuk membatasi pergerakan orang. Perdana Menteri India Narendra Modi juga meminta warga menjaga jarak, bahkan dengan keluarga. Namun, hal tersebut sulit dilakukan oleh sekitar 74 juta orang di India yang hidup berimpitan di permukiman kumuh. Menjaga jarak satu sama lain mustahil dilakukan oleh kalangan menengah ke bawah. Sepekan diterapkan, lockdown di India belum menunjukkan dampak positif. Penerapan lockdown di seluruh India membuat hampir seluruh badan usaha tutup. Banyak para pekerja harian kesulitan keuangan karena menganggur.

Sejumlah penduduk dilaporkan protes karena pengiriman pasokan bahan makanan tak merata. Belum lagi ancaman kekerasan oleh polisi jika warga nekat keluar rumah, meski untuk belanja persediaan di rumah. Pandemi virus corona juga kian mempersulit akses penggunaan toilet karena fasilitas sanitasi dan akses air terbatas. Penghuni di permukiman kumuh di Mumbai mengaku tak mungkin hanya berdiam diri di rumah selama lockdown karena mereka membutuhkan air. Kawasan perumahan yang sempit - membuat hampir semua rumah tidak memiliki saluran air atau fasilitas sanitasi memadai. Larangan bekerja oleh pemerintah India juga dikecualikan bagi beberapa sektor, seperti petugas kebersihan yang tidak punya pilihan. Mereka dianggap memberikan layanan penting dan dikecualikan dari lockdown. Namun, tidak diberikan peralatan pelindung, seperti masker dan sarung tangan. Hingga hari ini, jumlah kasus positif di India mencapai 18.985 kasus, dengan 603 orang meninggal dunia. ${ }^{17}$

Inggris, Pemerintah Inggris menerapkan lockdown ${ }^{18}$ selama tiga pekan. Langkah tersebut diambil karena warga mengabaikan imbauan tidak bepergian guna mencegah penyebaran virus corona. Semua pertokoan yang tidak terlalu penting ditutup. Begitupun tempat ibadah, sehingga seluruh kebaktian ditiadakan termasuk untuk pernikahan dan baptis. Wakil kepala petugas medis di Inggris Jenny Harries mengungkapkan, aturan ketat ini dapat berlangsung hingga enam bulan. Pemerintah membutuhkan dua atau tiga bulan untuk melihat apakah kebijakan lockdown efektif membendung pandemi. Sejauh ini, ada 22.454 orang di Inggris yang terinfeksi virus corona. Sebanyak $1.411 \mathrm{di}$ antaranya meninggal, dan 170 lainnya dinyatakan sembuh. Beberapa pejabat negara dinyatakan positif terinfeksi yakni Perdana Menteri Inggris Boris

17 Lihat “India Under COVID-19 Lockdown” dalam www.thelancet.com, hlm. 1315.

18 Lihat Nur Rohim Yunus dan Annissa Rezki, "Kebijakan Pemberlakuan Lockdown sebagai Antisipasi Penyebaran Corona Virus Covid-19", Salam, 3 (2020), hlm, 228. 
Johnson, Menteri Kesehatan Matt Hancock, kepala petugas medis Chris Whitty, dan kepala penasihat PM Johnson, Dominic Cummings.

\section{Definisi Teori}

Teori The Law of non Transferability of Law dapat diartikan sebagai "Hukum tentang tidak dapat dialihkannya suatu hukum". Atau diartikan sebagai "Hukum suatu bangsa tidak dapat dialihkan / ditransfer begitu saja kepada bangsa lain", maksudnya suatu negara / tempat tidak dapat memberlakukan hukum di suatu negara yang diambil dari hukum negara lain, sekalipun negara tersebut lebih maju. ${ }^{19} \mathrm{Hal}$ ini dikarenakan dalam banyak hal terdapat kemungkinan terjadinya perbedaan antara suatu bangsa dengan bangsa lainnya, seperti sosio-politik, budaya penegakan hukum dan ketaatan masyarakat terhadap hukum, dan lain sebagainya.

Oleh karena itu, ketelitian dalam hal memilah dan kecerdasan dalam hal mempertimbangkan relevansi penerapan suatu hukum yang diambil dari negara lain sangat diperlukan dalam hal ini, mengingat betapa penting efektifitas suatu hukum itu sendiri. demikian itu dalam istilah yang digunakan oleh Eugen Erlich adalah law is not society, ${ }^{20}$ di mana perbedaan sosial-kultural menjadikan suatu hukum memiliki nilai kemanfaatan berdasarkan sudut pandang kemungkinannya untuk diterapkan di suatu tempat, maka kemanfaatan atas perealisasian suatu aturan hukum di suatu tempat belum tentu akan memiliki kemanfaatan yang sama_bahkan berbalik menjadi kerusakan_jika direalisasikan di tempat yang lain.

\section{Efektifitas Suatu Hukum}

Suatu hukum dapat dikatakan efektif jika memenuhi beberapa kriteria sebagaimana yang telah banyak dirumuskan oleh para sosiolog dan pakar hukum. Diantaranya apa yang telah dirumuskan oleh Lon Fuller, sebagaimana berikut:

a. Harus ada peraturannya terlebih dahulu;

b. Peraturan itu harus diumumkan;

c. Peraturan itu tidak boleh berlaku surut;

d. Perumusan peraturan harus dapat dimengerti oleh masyarakat luas;

e. Hukum tidak boleh meminta dijalankannya hal-hal yang tidak mungkin;

f. Diantara sesama peraturan tidak boleh terdapat pertentangan satu sama lain;

19 Bambang Santoso, "Relevansi Pemikiran Teori Robert B. Seidman tentang Law of non Transferability of Law dengan Upaya Pembangunan Hukum Nassional Indonesia", Yustisia, 70 (Januari, 2017), hlm, 3.

20 Satria Sukananda dan Chrisinta Dewi Destiana, “Evaluasi Penegakan Hukum Tindak Pidana Korupsi Oleh Komisi Pemberantasan Korupsi (KPK) dalam Perspektif Sosiologi Hukum, Jurnal Peradilan Indonesia, (Desember, 2019), hlm, 66. 
g. Peraturan harus tetap dan tidak boleh sering diubah-ubah;

h. Harus terdapat kesesuaian antara tindakan para pejabat hukum dengan peraturan yang telah dibuat.

Kendatipun demikian, sebaik apapun hukum yang dibuat pada akhirnya sangat ditentukan oleh budaya hukum yang berupa nilai, pandangan serta sikap dari masyarakat yang bersangkutan. Jika budaya hukum diabaikan, maka dapat dipastikan akan terjadi kegagalan dari sistem hukum modern yang ditandai dengan munculnya berbagai gejala seperti, kekeliruan informasi mengenai isi peraturan hukum yang ingin disampaikan kepada masyarakat, muncul perbedaan antara apa yang dikehendaki oleh undang-undang dengan praktek yang dijalankan oleh masyarakat, Masyarakat lebih memilih untuk tetap bertingkah laku sesuai dengan apa yang telah menjadi nilai-nilai dan pandangan dalam kehidupan mereka.

Daniel S. Lev kemudian menjelaskan tentang sistem hukum dan budaya hukum, dimana menurutnya sistem hukum itu menekankan pada prosedur, sedangkan budaya hukum sendiri terdiri dari 2 komponen yaitu:

a. Nilai-nilai hukum prosedural yang berupa cara-cara pengaturan masyarakat dan manajemen konflik;

b. Nilai-nilai hukum substansial yang berupa asumsi-asumsi fundamental mengenai distribusi maupun penggunaan sumber-sumber di dalam masyarakat, terutama mengenai apa yang adil dan tidak adil menurut masyarakat.

Lebih jauh dapat penulis sampaikan bahwa suatu sistem hukum dapat dikatakan efektif apabila tingkah laku manusia di dalam masyarakat sesuai dengan apa yang telah ditentukan dalam peraturan hukum yang berlaku. Paul dan Dias dalam hal ini mengemukakan 5 syarat yang harus dipenuhi untuk mengefektifkan sistem hukum, antara lain sebagaimana berikut ini:

a. Mudah tidaknya makna aturan hukum itu untuk dipahami;

b. Luas tidaknya kalangan di dalam masyarakat yang mengetahui isi aturan hukum yang bersangkutan;

c. Efisien dan efektif tidaknya mobilisasi aturan hukum;

d. Adanya mekanisme penyelesaian sengketa yang tidak hanya mudah dijangkau oleh masyarakat tetapi juga harus cukup efektif dalam menyelesaikan sengketa;

e. Adanya anggapan dan pengakuan yang merata di kalangan masyarakat bahwa aturan dan pranata hukum itu memang sesungguhnya berdaya kemampuan yang efektif. ${ }^{21}$

${ }^{21}$ Fithriatus Shalihah, Sosiologi Hukum, Cet. 1 (Depok: Rajawali Press, 2017), hlm, 66. 
Dalam hal ini Seidman menegaskan bahwa terdapat beberapa variabel utama yang dapat digunakan untuk mengetahui apakah seseorang akan bertindak sesuai dengan peraturan hukum atau tidak, diantaranya adalah sebagaimana berikut:

a. Apakah normanya telah disampaikan (sosialisasi produk hukum);

b. Apakah normanya serasi dengan tujuan yang diterapkan bagi posisi itu (sinkronisasi produk hukum);

c. Apakah si pemegang peran digerakkan oleh motivasi yang menyimpang (faktor motivasi).

Pengejawantahan dari teori yang digagas oleh Seidman tersebut mengajarkan bahwa para pemegang peran (pejabat hukum) dapat memiliki motivasi, baik yang berkehendak maupun yang tidak berkehendak untuk menyesuaikan diri dengan norma. Sementara itu, pemegang peran juga dapat memiliki tingkah laku yang mungkin konform maupun yang mungkin tidak konform. Teori ini kemudian dikenal sebagai teori penyimpangan. Terjadinya ketidakcocokan antara peranan yang diharapkan oleh norma dengan tingkah laku yang nyata dari masyarakat sebagaimana dijelaskan oleh teori penyimpangan di atas, dikarenakan fungsi hukum tidak lagi hanya sekedar sebagai kontrol sosial saja melainkan sebagai sarana untuk membentuk pola tingkah laku yang baru sehingga melahirkan masyarakat baru yang dicitacitakan. Berdasarkan konsep yang modern, fungsi hukum seperti ini digunakan sebagai sarana untuk melakukan social engineering. Namun sayangnya, fungsi hukum sebagai social engineering ternyata tidak selalu didukung oleh kehidupan sosial dimana hukum itu diterapkan sehingga harus ditunjang dengan tingkat kesadaran hukum masyarakat yang tinggi.

Dengan demikian, pembinaan kesadaran hukum hendaknya berorientasi pada usaha untuk memasyarakatkan nilai-nilai yang mendasari peraturan hukum yang bersangkutan serta memperhatikan faktor komunikasi hukumnya agar isi peraturan hukum tersebut dapat diketahui oleh masyarakat luas sebagai sasaran dari peraturan hukum itu sendiri. ${ }^{22}$ Efiesiensi suatu peraturan hukum sangat penting, juga cara pandang dan pola berpikirnya, perlu meninjau hubungan hukum dengan faktor-faktor serta kekuatan-kekuatan sosial diluarnya. Menurut Seidman setiap undang-undang sekali dikeluarkan akan sangat memungkinkan mengalami perubahan, baik melalui perubahan normal ataupun melalui cara-cara yang ditempuh oleh birokrasi ketika bertindak dalam bidang politik, ekonomi, sosial dan lain sebagainya. Perkembangan masyarakat dan susunannya yang semakin kompleks dewasa ini, mengkehendaki peraturan hukum yang mengikuti perkembangan masyarakat tersebut. Hal itu dikarenakan hampir seluruh aspek

${ }^{22}$ Fithriatus Shalihah, Sosiologi Hukum, hlm, 68. 
kehidupan dewasa ini telah ada aturan dalam perundang-undangan, hukum memegang peran penting dalam kerangka kehidupan sosial masyarakat modern. ${ }^{23}$

\section{Budaya Hukum Cina}

Dunia ekonomi Cina memiliki budaya yang sangat mendukung atas kemajuannya, diantaranya adalah apa yang telah dipercayai sebagai suatu sistem moral. Seperti seorang karyawan diharapkan dapat menjadi seseorang yang mampu bersikap sebagai pengikut, penurut dan kerapkali sebagai seorang yang tidak perlu melalakukan banyak pertanyaan dalam setiap pekerjaan. Sedangkan seorang pemimpin dianggap sebagai segalanya dalam hal keberwenangannya sebagai pemimpin, paling berkompeten daripada selainnya dalam suatu kelompok. Pun demikian halnya dengan lingkungan sosial, sikap masyarakat Cina cenderung menerima aturan daripada berusaha mengubahnya. Mereka mencari kecocokan dirinya, kesamaan bagi suatu tindakan yang dapat membuat keharmonisan dalam hidup dan lingkungan mereka. Bagi masyarakat Cina pembuatan keputusan haruslah dilakukan secara perlahan-lahan dan bertahap, karena masyarakat Cina memiliki kecenderungan etika utilitarianisme yang tinggi. ${ }^{24}$

Dalam hal ini Seidman menyatakan bahwa pembentukan suatu aturan hukum dan implementasi yang dihasilkan darinya tidak mungkin bisa terlepas dari beberapa faktor yang sangat berpengaruh terhadap hal tersebut seperti faktor ekonomi, faktor politik, faktor budaya, faktor pendidikan, dan faktor kepentingan, serta semua kekuatan yang berasal dari individu dan masyarakat yang terdapat di luar proses tersebut. Setiap konsep hukum memengaruhi, mendorong atau memaksa agar suatu kegiatan dilakukan oleh lembaga pembuat peraturan dan lembaga kekuasaan negara. Dalam hal ini terdapat tiga komponen utama yang memiliki pengaruh besar yakni lembaga legislatif, Yudikaif dan Eksekutif.

Selain itu Seidman juga membedakan tipologi masyarakat menjadi dua, Pertama, masyarakat berdasarkan pada kesepakatan nilai-nilai (value concensus), pembuatan auatu aturan hukum merupakan pencerminan nilai-nilai yang disepakati oleh masyarakat itu sendiri. Kedua, masyarakat dengan model konflik. Nilai-nilai yang berlaku di masyarakat berada dalam situasi konflik satu sama lain, sehingga keadaan ini juga akan tercermin dalam pembuatan hukumnya.

Maka semua pembuatan keputusan dalam hal ini merupakan suatu kesatuan dari keyakinan para pembuat keputusan tersebut. Individu-individu pembuat keputusan baik yang berperan sebagai masyarakat biasa, lembaga legislatif maupun lembaga penegak hukum merupakan subyek kehendak utama dalam tatanan sosial, di mana keyakinannya dalam membuat suatu keputusan ditentukan oleh lingkungan politik, sosial dan ekonomi.

${ }^{23}$ Nurhadi, “Teori Hukum Progresif dalam Menyelesaikan Sengketa Bisnis Keuangan Syariah”, Samudera Keadilan, 2 (Juli, 2019), hlm, 156.

${ }^{24}$ Daryono dan Dini Anggraheni, “Etos Dagang Orang Islam Jawa dan Budaya Dagang Etnis Cina dalam Tantangan Peningkatan Perekonomian Indonesia", Jurnal Iqtisad, 2 (2018), hlm, 20. 
Dari beberapa hasil data yang telah terkumpul dapat dipahami bahwa Cina memiliki kekuatan ekonomi yang tinggi, sehingga sangat memungkinkan untuk melakukan sistem pencegahan Covid-19 dengan cara lockdown. Selain itu dari segi budaya masyarakatnya penerapan sistem lockdown untuk mencegah penyebaran Covid-19 sangat memungkinkan bagi Cina, sehingga keberhasilannya dalam pencegahan penyebaran virus tersebut sangat berkaitan. Hal ini sebagaimana yang telah dicatat oleh salah satu peneliti yang menyatakan bahwa pada situasi semacam ini Cina merupakan satu-satunya negara yang mampu bangkit dan pulih dalam hal kondisi perekonomian. ${ }^{25}$

Selain penerapan sistem lockdown terdapat penyebarluasan pengobatan medis yang direalisasikan oleh Cina dalam proses pemulihan diri dari Covid-19, yakni Chinese Medicine (CM). Beberapa teknik pengobatan yang dirujuk dari pengalaman atas penanganan terhadap penyebaran virus-virus lama yang pernah menimpa Cina, di mana CM berfungsi untuk pencegahan dan pengobatan dalam hal penyebaran virus. ${ }^{26}$

Oleh karena itu, upaya yang perlu dilakukan dewasa ini berkaitan dengan penanganan COVID-19 _yang hingga saat ini masih belum dapat sembuh total_ terdapat beberapa teknik penanganan yang menurut hemat penulis sangat relevan diterapkan di Indonesia. Hal itu sebagaimana yang telah diuraikan oleh Muhammad Habib dalam salah satu artikelnya ${ }^{27}$, sebagaimana berikut ini:

a. Penguatan dosis peran pemerintah dalam penanganan COVID-19;

b. Meninjau kapasitas pemerintah daerah dalam rangka melawan COVID-19. Kapasitas tersebut dapat berupa fasilitas pelayanan kesehatan rujukan, ketersediaan anggaran, memenuhi kebutuhan alat-alat medis yang dibutuhkan, menyediakan sarana dan prasarana yang dapat dimanfaatkan untuk keadaan darurat;

c. Menggalakan imunitas daerah.

Demikian itu merupakan tawaran-tawaran yang paling sederhana namun memiliki peran signifikan dalam menghadapi dampak COVID-19 secara jangka panjang. Namun demikian, tidak melulu upaya penanganan dibebankan kepada pihak-pihak yang berwenang. Melainkan harus ada kompromi dan upaya saling mendukung antara pemerintah beserta jajarannya dengan masyarakat secara luas, sehingga dengan adanya kompromi tersebut dapat membangkitkan semangat budaya hukum yang menghasilkan aturan yang memberikan kemashlahatan umat dan umat yang mematuhi aturan.

${ }^{25}$ Lihat Mohammad Danil Arifin, “Impacts of Coronavirus COVID-19 on the Global Shipping and Maritime Industry in Indonesia and How to Overcome the Coronavirus Outbreak Based on WHO and IMO Recommendations", OSF Preprints, (Mei, 2020), hlm. 3.

${ }^{26}$ Lou Hui, Tang Qiao-ling, dkk., “Can Chinese Medicine Be Used for Prevention of Corona Virus Disease 2019 (COVID-19)? A Review of Historical Classics, Research Evidence and Current Prevention Programs", Chinese Journal of Integrative Medicine, (2020), hlm. 2.

${ }^{27}$ Lihat Muhammad Habib Abiyan Dzakwan, "Memetakan Kesiapan Pemerintah Daerah dalam Menangani COVID-19”, CSIS Commentaries, No. 1 (April, 2020), hlm. 5. 


\section{KESIMPULAN}

Cina menganggap bahwa Covid-19 merupakan suatu virus yang tergolong baru di era dewasa ini. Populasi perekonomian dunia sangat memungkinkan terjadi penurunan drastis karenanya. Oleh karena itu Cina dengan dukungan para ilmuan dan tenaga medis selalu berusaha untuk dapat merealisasikan sikap-sikap yang tanggap dan antisipatif terhadap keberadaan Covid-19 ini.

Dalam hal ini terdapat beberapa metode pencegahan yang dilakukan oleh Cina sehingga mampu menduduki pringkat pertama dalam menangani penyebaran Covid19. Diantaranya adalah dengan cara melakukan lockdown dan Chinese Medicine (CM). Demikian itu tentu saja dengan melakukan banyak pertimbangan, tidak semerta-merta tanpa kesiapan yang matang memberlakukan upaya-upaya pencegahan tersebut.

Berdasar hasil analisis dengan menggunakan teori Seidman, The Law of non Transferability of Law dapat ditarik suatu benang merah bahwasanya apa yang telah dilakukan oleh Cina dalam hal proses pencegahan terhadap penularan Covid-19 tidak bisa secara semerta-merta diikuti (untuk direalisasikan) oleh negara-negara lain. Hal itu dikarenakan perlu adanya pertimbangan dari banyak aspek, seperti kekuatan ekonomi, budaya penegakan hukum dan ketaan masyarakat terhadap hukum, dan lain sebagainya. Oleh karena itu teori yang di gagas oleh Seidman tersebut dapat dijadikan sebagai dalil (landasan hukum) bagi setiap negara yang merasa tidak memungkinkan untuk menerapkan sistem pencegahan terhadap penyebaran Covid-19. Sehingga harus menyesuaikannya berdasarkan kemampuan dan kemungkinan yang dianggap lebih efektif.

\section{REFERENSI}

Anggraeni, RR Dewi. "Wabah Pandemi Covid-19, Urgensi Pelaksanaan Sidang Secara Elektronik," 'Adalah, Volume 4, No. 1 (2020)

Arifin, Mohammad Danil. (2020). Impacts of Coronavirus COVID-19 on the Global Shipping and Maritime Industry in Indonesia and How to Overcome the Coronavirus Outbreak Based on WHO and IMO Recommendations". OSF Preprints, 3.

Bellomarini, Luigi., Marco Benedetti, dkk. (2020). COVID-19 and Company Knowladge Graphs: Assessing Golden Powers and Economic Impact of Selective Lockdown via AI Reasoning. Arxiv Preprint, 4.

Budiana, Ulfa dan Muhammad Djafar Saidi. (2020). Efektivitas Penegakan Hukum Pajak Bagi Wajib Pajak Hotel. Al-Azhar Islamic Law Review (1), 59.

Daryono dan Dini Anggraheni. (2018). Etos Dagang Orang Islam Jawa dan Budaya Dagang Etnis Cina dalam Tantangan Peningkatan Perekonomian Indonesia. Jurnal Iqtisad. (2), 20.

Dzakwan, Muhammad Habib Abiyan. (2020). Memetakan Kesiapan Pemerintah Daerah dalam Menangani COVID-19". CSIS Commentaries. (1), 5.

Fuady, Munir. (2011). Teori-teori dalam Sosiologi Hukum. Jakarta: Kencana.

https://www.who.int., 
Hui, Lou., Tang Qiao-ling, dkk. (2020). Can Chinese Medicine Be Used for Prevention of Corona Virus Disease 2019 (COVID-19)? A Review of Historical Classics, Research Evidence and Current Prevention Programs. Chinese Journal of Integrative Medicine. 2.

Khoimah, Nurul Khusnul. (2020). Lockdown COVID-19 ditinjau dari Teori Filsafat, Pancasila sebagai Filsafat dan Bentuk Negara Indonesia. Academia. 3.

Machendrawaty, Nanih., Yuliani, dkk. (2020). Optimalisasi Fungsi Mesjid di Tengah Pandemic Covid 19 (Telaah Syar'i, Regulasi dan Aplikasi). KTI UIN Sunan Gunung Djati Bandung. 5.

Maggalatung, A.S.; Aji, A.M.; Yunus, N.R. How The Law Works, Jakarta: Jurisprudence Institute, 2014.

Mukaromah, Vina Fadhrotul. China Tak Lagi Masuk Daftar, Ini 10 Negara dengan Kasus COVID-19 Terbanyak di Dunia. dalam https://www.google.com/amp.kompas.com/tren/read/2020/05/02/094100465/.

Nurhadi. (2019). Teori Hukum Progresif dalam Menyelesaikan Sengketa Bisnis Keuangan Syariah. Samudera Keadilan. (2), 156.

Santoso, Bambang. (2007). Relevansi Pemikiran Teori Robert B. Seidman tentang Law of non Transferability of Law dengan Upaya Pembangunan Hukum Nassional Indonesia. Yustisia. (70), 3.

Sebayang, Rehia. Dituntut 90 Ribu T Gegara Corona, Ini Jawaban Cina ke AS. dalam https://www.cnbcindonesia.com/news/20200422083748-4-153543/.

Shalihah, Fithriatus. (2017). Sosiologi Hukum. Depok: Rajawali Press.

Sukananda, Satria dan Chrisinta Dewi Destiana. (2019). Evaluasi Penegakan Hukum Tindak Pidana Korupsi Oleh Komisi Pemberantasan Korupsi (KPK) dalam Perspektif Sosiologi Hukum. Jurnal Peradilan Indonesia. No. 2, 66.

Syawfi, Idil. (2020). Implikasi Pandemi Covid-19 Terhadap Hubungan Internasional: Menuju Dunia Paska-Liberal. Jurnal Ilmiah Hubungan Internasional. 25.

Tahali, Ahmad. (2018). Hukum Adat di Nusanara Indonesia. Jurnal Syariah Hukum Islam. (2), 69.

Wahid, Soleh Hasan. (2019). Dinamika Fatwa dari Klasik ke Kontemporer (Tinjauan Karakteristik Fatwa Ekonomi Syariah Dewan Syariah Nasional Indonesia, DSNMUI). Yudisia; Jurnal Pemikiran Hukum dan Hukum Islam. (2), 193.

www.thelancet.com,

Yunus, N.R.; Anggraeni, RR Dewi.; Rezki, Annissa. "The Application of Legal Policy Theory and its relationship with Rechtsidee Theory to realize Welfare State," 'Adalah, Volume 3, No. 1 (2019)

Yunus, N.R.; Rezki, Annissa. "Kebijakan Pemberlakuan Lock Down Sebagai Antisipasi Penyebaran Corona Virus Covid-19," Salam: Jurnal Sosial dan Budaya Syar-i, Volume 7, No. 3 (2020).

Yunus, Nur Rohim dan Annissa Rezki. (2020). Kebijakan Pemberlakuan Lockdown sebagai Antisipasi Penyebaran Corona Virus Covid-19. Salam, (3), 228.

Yusuf, Muhammad. (2019). Efektivitas Pelaksanaan Hukum Jinayat di Aceh. Samarah; Jurnal Hukum Keluarga dan Hukum Islam. (1), 120. 